Review Article

\section{Three modern serological methods to detect plant viruses}

\author{
Mahmoud Hamdy Abd El-Aziz* \\ Plant Pathology Institute, Agricultural Research Center, Alexandria, Egypt
}

\section{Abstract}

The use of enzyme linked immunosorbent assay (ELISA) for the detection of plant viruses is well documented. It proved to be a very valuable detection tools for the plant viruses. The efficiency of the ELISA technique was for practical purpose independent of the ratio of antibodies to antigen. This avoids the necessity of making specific enzyme conjugates for each antigen to be tested and eliminates the extreme specificity, thus allowing for quantitative evaluation of strain relationships. The advantages of indirect ELISA are sample. It needs only to be macerated and added to the plate. The crude antiserum could be used, although it should be cross absorbed before to prevent spurious host reaction. Single commercially available second antibody conjugate is utilized, thus eliminating the problems of preparing and storing many different conjugated antisera. Blotting technique has become widely used for specific identification of nucleic acid and proteins. This dot assay was modified to detect protein by spotting the antigen on a nitrocellulose membrane and incubating the membrane in test antibody followed by incubation in peroxidase-conjugated second antibody to the first antibody, and by development in 4-chloro-1-naphthol. The above procedure termed dot blot immunobinding assay (DBIA). The technique of tissue blotting on nitrocellulose membrane was described for detection of plant viruses in infected plants. Tissue blots were made by pressing with a firm and gentile force, the freshly cut tissue surface on nitrocellulose membranes. The possibility of using both sides of the nitrocellulose membrane (NCM) by tissue blot immuno assay (TBIA) for the detection plant viruses. In an effort to reduce the cost of virus assays, different types of regular paper were evaluated as possible replacements for the commonly used nitrocellulose membrane (NCM) as the solid phase in the tissue-blot immunoassay (TBIA) were used. Comparisons between different serological methods were demonstrated by many investigators Dot immunobinding was eight times more sensitive for detection of PVX and four times more sensitive for detection of PVS and PVY than DAS-ELISA.

\author{
More Information \\ *Address for Correspondence: Mahmoud \\ Hamdy Abd El-Aziz, Plant Pathology Institute, \\ Agricultural Research Center, Alexandria, Egypt, \\ Tel: +201229556042; \\ Email: maziz70@yahoo.com
}

\begin{abstract}
Submitted: 23 September 2019
Approved: 09 October 2019

Published: 10 October 2019
\end{abstract}

How to cite this article: Abd El-Aziz MH. Three modern serological methods to detect plant viruses. J Plant Sci Phytopathol. 2019; 3: 101-106.

DOI: dx.doi.org/10.29328/journal.jpsp.1001039

Copyright: @ 2019 Abd El-Aziz MH. This is an open access article distributed under the Creative Commons Attribution License, which permits unrestricted use, distribution, and reproduction in any medium, provided the original work is properly cited

Keywords: ELISA; TBIA; DBIA; Antibodies; NCM

Check for updates

\section{Introduction}

The serological methods of diagnosis, detection and identification of viruses in plants play a vital role [1]. Traditional diagnosis of plant viruses requires bioassay, an indicator plant, determination of host range, symptomatology, virus particle morphology (size and shape), and vector relations [2,3]. A single diagnostic test or assay may provide adequate information on the identity of a virus but a combination of methods is generally needed which are specific, sensitive and inexpensive [4,5]. However, progress in molecular biology, biochemistry and immunology has led to the development of many new, accurate, rapid and less labour-intensive methods of virus detection [6]. Technologies for the molecular detection of plant pathogens have already undergone two major breakthroughs well over the past three decades [1]. The first was the advent of antibody based detection, in particular monoclonal antibodies and enzyme-linked immunosorbent assay $[7,8]$. There are various immuno-diagnostic and molecular-diagnostic techniques presently available in field of virology and these are divided into two: Protein based techniques which include precipitation/ agglutination tests, enzymes linked immunosorbent assay (ELISA), dot immunoblotting assay (DBIA) and tissue blot immunobinding assay (TBIA). Lawson [9] has mentioned that appropriate screening procedures have been conducted in order to certify any plant free of certain pathogen using ELISA, DBIA, TBIA, PCR, DNA probes.

\section{Enzyme linked immunosorbent assay}

The use of enzyme linked immunosorbent assay (ELISA) for the detection of plant viruses is well documented and proved to be a very valuable detection tools for the plant viruses. In addition, the specificity of the test can preclude detection of even closely related strains of the same virus [10-14].

Firstly, Clark and Adams [8], found that unlike nearly all 
other serological techniques in plant virology which were based on the formation and detection of immune precipitates, the ELISA technique released upon the sensitive detection of non-precipitates reaction, made possible by the use of enzyme-labeled antibodies. There are two main consequences of this difference in reaction principle. The efficiency of the ELISA technique was for practical purpose independent of the ratio of antibodies to antigen. Thus once the appropriate concentrations were ascertained these were applicable for subsequent test for detecting virus at all concentrations and the reaction of enzyme labeled antibody was function of virus concentration, so the technique has high quantitative potential. To determine the sensitivity of ELISA Pesic and Hiruki [15], found that the quantitative response over concentration range of AMV tested it was indicated that ELISA was responsible to both variation in $\delta$-globulin concentration and enzyme conjugated $\delta$-globulin dilution. The minimum quantity of AMV detectable, $1 \mathrm{ng} / \mathrm{ml}$ was obtained with the coating-globulin at a concentration of $2 \mu \mathrm{g} / \mathrm{ml}$ and enzymeconjugated $\delta$-globulin at $1 / 1000$ and $1 / 2000$ dilution or at $1 \mu \mathrm{g} / \mathrm{ml}$ and 1/1000 dilution, respectively. An increased dilution of enzyme-conjugated $\delta$-globulin $1 / 4000$ reduced the levels of detection of AMV antigen to $16 \mathrm{ng} / \mathrm{ml}$ with the coating $\delta$-globulin at a concentration of $2 \mu \mathrm{g} / \mathrm{ml}$ and $250 \mathrm{ng} /$ $\mathrm{ml}$ with $\delta$-globulin at $1 \mu \mathrm{g} / \mathrm{ml}$. Indirect ELISA was an enzyme labeled anti Ig as a second antibody to detect the antigen antibody complex on the solid face. This avoids the necessity of making specific enzyme conjugates for each antigen to be tested and eliminates the extreme specificity, thus allowing for quantitative evaluation of strain relationships [16-18]. Indirect ELISA was used in detection and confirmation infection of many plant viruses [1,4,14,19-21]. Bar-Joseph, et al. [22], found that the dissociation reactions of four plant viruses: citrus tristeza virus (CTV), carnation mottle virus (CarMV), carnation yellow fleck virus (CYFV), and tobacco mosaic virus (TMV) and their respective "y-globulin alkaline phosphatase conjugates, sandwiched to antibody microplates, were examined. Treatment with $0.2 \mathrm{M}$ glycine-HCI buffer $\mathrm{pH}$ 2.2 for $60 \mathrm{~min}$ caused the double antibody sandwiches (DAS) of CTV and CarMV to dissociate from the antibody-coated microplates. In similar treatments CYFV was eluted less efficiently. The TMV double-sandwich remained undissociated by acidification but it could be partially dissociated under alkaline conditions ( $\mathrm{pH}$ 12.1). The application of microplate recycling for economizing routine large-scale screening of CTV is described. Lommel, et al. [17], reported that indirect ELISA could be very useful as routine plant virus detection tool for virus disease diagnosis and surveys where accurate quantitative is not for concern. The advantages of indirect ELISA are sample need only to be macerated and added to the plate, crude antiserum could be used, although it should be cross absorbed to prevent spurious host reaction and single, commercially available second antibody conjugate is utilized, thus eliminating the problems of preparing and storing many different conjugated antisera as Abd El-Aziz and Younes [23].

\section{Dot blot immunobinding assay (DBIA)}

Blotting technique has become widely used for specific identification of nucleic acid and proteins. This dot assay was modified to detect protein by spotting the antigen on a nitrocellulose membrane and incubating the membrane in test antibody followed by incubation in peroxidase-conjugated second antibody to the first antibody, and by development in 4-chloro-1-naphthol. The above procedure termed dot blot immunobinding assay (DBIA). It was used to screen the supernatants of hybridomas for monoclonal antibodies and screen pathological sera for multiple antibodies [24]. The advantages of DBIA that it could detect much lower amounts of virus because of the very small sample volume ( $2 \mu$ l compared with $250 \mu \mathrm{l}$ for ELISA) as Powell, [25] and Abd El-Aziz and Younes, [23] or ( $4 \mu \mathrm{l}$ compared with $250 \mu \mathrm{l}$ for ELISA) as Abd El-Aziz, et al., [26]. A potential drawback to the DBIA is that a large volume $50 \mathrm{ml}$ relatively concentrated $(1 \mathrm{mg} / \mathrm{ml})$ virus antiserum was needed, but antivirus antibodies solution can be stored at least for 6 months and used at least 600 samples without appreciable loss of sensitivity [25,27]. Zheng, et al. [28], found by using either polyclonal or monoclonal antibodies and both direct and indirect methods in modified DBIA that it produced satisfactory results. The assay detected $0.35 \mathrm{ng}$ of purified cowpea mosaic virus (CpMV) and was superior to ELISA and immunosorbent electron microscopy methods. Berger, et al. [29], detected pictogram quantities of potyviruses using a dot immunobinding assay. Al Khalaf, et al. [30] and Abd El-Aziz and Younes, [23] used of the two faces of nitrocellulose membrane in tissue blot immunoassay for the detection of Bean yellow mosaic virus and the possibility of its mechanically transmitted from the printed membrane to the host plant. In an effort to reduce the cost of virus assays, different types of regular paper were evaluated as possible replacements for the commonly used nitrocellulose membrane (NCM) as the solid phase in the tissue-blot immunoassay (TBIA) used to detect Alfalfa mosaic virus, Bean yellow mosaic virus and Broad bean stain virus (BBSV) in faba bean tissue, and Barley yellow striate mosaic virus in barley tissue. Among the many types of paper evaluated, HewlettPackard (HP) non-glossy plotter paper proved to be adequate for detection of all the above viruses. After printing (blotting) of the samples to be tested and blocking with $2 \%$ gelatin (for one hour at $37 \mathrm{oC}$ ) or using $0.1 \%$ Roche blocking reagent (for one hour at room temperature), satisfactory results were produced. This paper could also be used to detect BBSV in groups consisting of 15 young lentil seedlings. HP non-glossy blotter paper was not as effective when testing for phloemlimited legume viruses such as Bean leaf roll virus (BLRV), Faba bean necrotic yellows virus (FBNYV) and Barley yellow dwarf virus (BYDV). White paper (manufactured by Soporcel, Portugal) was slightly more sensitive when used for BLRV and FBNYV detection in faba bean tissues and for BYDV in barley tissues. Since NCM represents $40 \%-50 \%$ of the cost of test reagents, using ordinary paper reduced costs considerably [21] and Makkouk and Kumari, [31]. 


\section{Tissue blotting immunoassay (TBIA)}

The technique of tissue blotting on nitrocellulose membrane was described for detection of plant viruses in infected plants. Tissue blots were made by pressing with a firm and gentile force, the freshly cut tissue surface on nitrocellulose membranes. Present antigen was then detected by enzyme labeled immunological probes [21]. Hsu and Lowson [32], mentioned that tomato spotted wilt virus (TSWV) was detected in tissue blots from infected leaves and stems. The presence of TSWV antigen in blot of infected tissues was evidence by the development purple color when primary antibodies were omitted from the reaction mixture, tissue blots from infected plants tissues developed purple color. The healthy control leaf and stem blots did not develop purple color, but leaf blots reaction green color of chlorophyll as [27]. Antigen-specific reactions were observed on tissue blots of faba bean necrotic yellow virus (FBNYV) infected plants, but not on those of non-inoculated faba bean plants. The red stain was restricted to midrib and secondary vein areas of leaf, petiole and stem sections indicating the restriction of FBNYV to vascular tissue [33]. Sherwood [34], compared between filter paper immunobinding assay, double antibody sandwich ELISA and western blotting for the detection and quantification of wheat streak mosaic virus (WSMV). He could detect 100pg of purified (WSMV) by DBIA on Whatman No.1 filter paper. He found that ELISA was a more quantitative assay, but the filter paper immunobinding assay and western blotting were more conservative of antiserum when only a few assays were required and could be run in a shorter period of time, while [23] compared between eight types of paper among them NCM $[12,35]$ stated that TBIA was sensitive enough to detect the virus in all parts of the plant and all growth stages. They obtained sensitive detection to ten legume viruses by using TBIA. Phloem limited viruses such as bean leaf roll luteovirus (BLRV), faba bean necrotic yellows virus (FBNYV) and viruses which generally invade systemically all plant tissues such as alfalfa mosaic virus (AMV), cucumber mosaic virus (CMV), broad bean mottle bromovirus (BBMV), broad bean wilt fabavirus (BBWV), pea seed-borne mosaic potyvirus (PSbMV), bean yellow mosaic potyvirus (BYMV), broad bean stain comovirus (BBSV) and broad bean true mosaic comovirus (BBTMV) were all easily detected by this method. Polyclonal and monoclonal antisera were used in the tests and both produced visible reactions. The test proved to be practical for testing groups of seedlings (2-25) after wrapping them together as one bundle by a Parafilm membrane and then cutting them with a razor blade and blotting the cut surface on a nitrocellulose membrane as one sample. It is suggested that this test can be easily employed for the detection of seed borne viruses after germinating the seeds and is more practical than regular ELISA. It can be completed in less than four hours without sacrificing sensitivity. It is cheaper and does not require sophisticated facilities.
Possibility of using processed nitrocellulose membrane by tissue blotting immunoassay (TBIA)

The unused face of processed nitrocellulose membrane already printed with plant tissues on one face, was tested for detection of CMV in infected N. glutinosa leaves using TBIA. Results indicated the possibility of using the empty face of nitrocellulose membrane even after 3 months from processing for detection of the $\mathrm{CMV}$, since it gave pronounced purple color with the infected leaf tissues (Figure 1) as Abd El-Aziz and Younes [6].

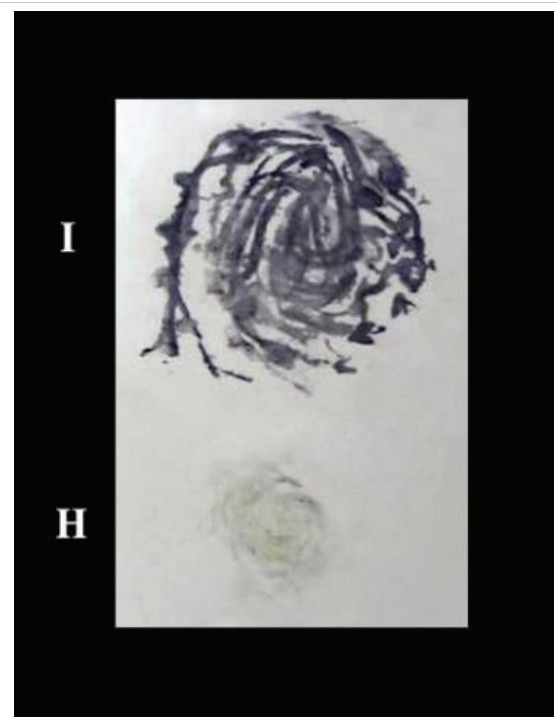

Figure 1: TBIA used for detection of CMV on the unused face of previously processed Nitrocellulose membrane. I: infected, H: healthy.

Use of the two faces of nitrocellulose membrane in tissue blot immunoassay (TBIA) for the detection of plant viruses

Al-Khalaf, et al. [30], found that the possibility of using both sides of the nitrocellulose membrane (NCM) by tissue blot immunoassay (TBIA) for the detection of Bean yellow mosaic virus (BYMV, genus Potyvirus, family Potyviridae) was investigated. Faba bean, lentil and pea plants infected with BYMV were printed on (i) one side of NCM, (ii) on both sides of NCM, and (iii) on the other side of a processed and/or un-processed NCM already printed with plant tissues on one side. The results showed that BYMV can be easily detected in faba bean, lentil and pea plants by TBIA using both sides of the membrane for processed and un-processed NCM. The use of both sides of the NCM reduced the cost of testing by $50 \%$. The results also showed that the virus cannot be transmitted mechanically from the printed infected blots on NCM to a healthy plant, and consequently, it does not permit the movement of the virus from one location to another distant location as (Figure 2) by Abd El-Aziz and Younes [6].

Use of the regular paper in tissue blot immunoassay (TBIA) and dot immunobinding assay (DBIA)

Sherwood [34], found that the filter paper immunobinding assay can be completed in 2-3h. this can be very useful in 
situation where only a quantitative diagnosis is required. The filter paper immunobinding assay is far the least expensive to conduct. Heide and Lange [36], reported in their experiments their found that DIB on plain paper could detect amounts as small as $30 \mathrm{pg}$ of purified PVX while Sherwood [34], could detect $100 \mathrm{pg}$ of purified wheat streak mosaic virus by DIB on Whatman No. 1 filter paper. They reported that the sensitivity of the DIB test on plain paper and on nitrocellulose membrane was found to be equally. Lange, et al. [37] found that the dot immuno binding (DIB) technique has been simplified so that it can be performed on plain paper. The usefulness on the technique is demonstrated by detecting the seed borne viruses Pea seed borne mosaic (PSbMV), Pea early browning (PEBV), Squash mosaic virus (SqMV), Bean common mosaic (BCMV) and Barley stripe mosaic (BSMV) directly from seed. This DIB technique does not require specialized equipment and is suitable for use in seed testing stations and quarantine services in industrialized as well as in developing countries [23], reported in their study, filter paper and plain papers were tested for the first time as alternatives for nitrocellulose membrane in TBIA. The promising aspect of TBIA is that is very rapid and can be carried out without the use of specialized equipment, inexpensive by using plain paper and it save time that it can be done in few hours as (Figure 3) by Abd El-Aziz and Younes [6]. Makkouk and Kumari [31], reported that in an effort to reduce the cost of virus assays, different types of regular paper were evaluated as possible replacements for the commonly used nitrocellulose membrane (NCM) as the solid phase in the tissue-blot immunoassay (TBIA) used to detect Alfalfa mosaic virus, Bean yellow mosaic virus and Broad bean stain virus (BBSV) in faba bean tissue, and Barley yellow striate mosaic virus in barley tissue. Among the many types of paper evaluated, Hewlett-Packard (HP) non-glossy plotter paper proved to be adequate for detection of all the above viruses. After printing (blotting) of the samples to be tested and blocking with $2 \%$ gelatin (for one hour at $37{ }^{\circ} \mathrm{C}$ ) or using $0.1 \%$ Roche blocking reagent (for one hour at room temperature), satisfactory results were produced. This paper could also be used to detect BBSV in groups consisting of 15 young lentil seedlings. HP non-glossy plotter paper was not as effective when testing for phloem-limited legume viruses such

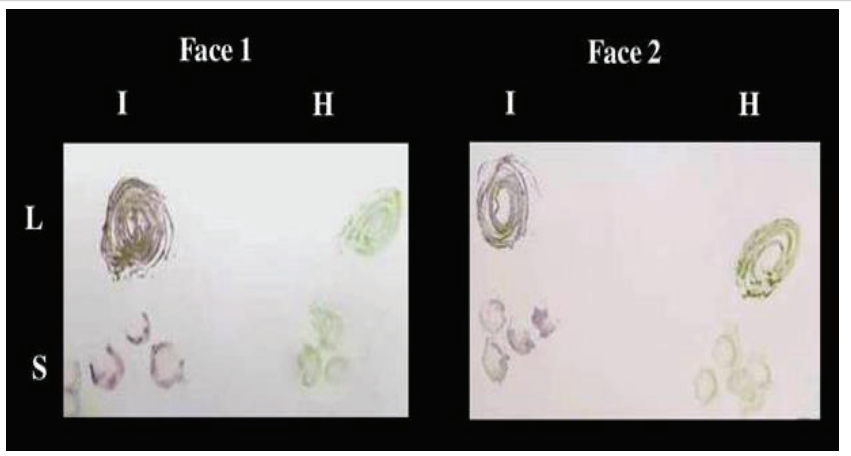

Figure 2: TBIA used for detection of CMV isolate 1 in infected leaves and stems of Nicotiana glutinosa plants on both faces at the same time on Nitrocellulose membrane. L: leaves, S: stems, I: infected, H: healthy.

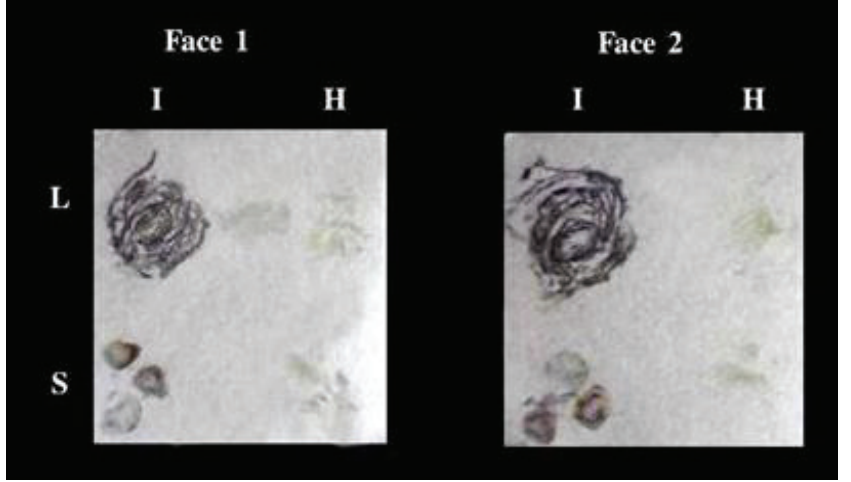

Figure 3: TBIA used for detection of CMV in infected leaves and stems of Nicotiana glutinosa plants on both faces at the same time on canson paper. L: leaves, S: stems, I: infected, H: healthy.

as Bean leaf roll virus (BLRV), Faba bean necrotic yellows virus (FBNYV) and Barley yellow dwarf virus (BYDV). White paper (manufactured by Soporcel, Portugal) was slightly more sensitive when used for BLRV and FBNYV detection in faba bean tissues and for BYDV in barley tissues. Since NCM represents $40 \%-50 \%$ of the cost of test reagents, using ordinary paper reduced costs considerably.

\section{Comparative studies for detection of viruses}

Comparisons between different serological methods were demonstrated by many investigators [1,12,34,38-41]. Dot blot immunobinding assay was eight times more sensitive for detection of potato virus X potyvirus (PVX) and four times more sensitive for detection of potato virus $S$ Carlavirus (PVS) and potato virus Y potyvirus (PVY) than DAS-ELISA [38]. The sensitivities of DBIA and ELISA for detection of Tomato spotted wilt virus (TSWV) antigens in infected leaf tissues were compared by detecting dilution endpoints of the same extract of infected Nicotiana benthamiana. In DBIA, the use of biotinylated mouse monoclonal antibodies and avidin enzyme conjugates improved the sensitivity by about four times when compared with the use of unlabeled mouse monoclonal antibodies and enzyme-label goat anti-mouse immunoglobulin conjugates. When biotinylated mouse monoclonal antibodies and avidin-alkaline phosphate conjugates in mouse monoclonal antibody coated ELISA plates were used, the sensitivity for detection of TSWV antigens in infected leaf tissue was only about one-eighth of that of DBIA with the same biotinylated antibody and avidin-enzyme conjugate preparation as detecting reagents [32]. ELISA proved to be the more accurate technique than DBIA for testing individual seeds on wide range of bean genotypes and bean common mosaic virus (BCMV) strains. The greater accuracy of ELISA is likely attributable to the quantitative readings in ELISA with a spectrophotometer [41]. Lockhart, et al. [42], detected barley yellow strait mosaic virus (BYSMV) at 1:25600 dilution of infected leaf extracts. They found that DBIA on NCM was 30 times as sensitive as double-antibody sandwich micro plate assay for detecting BYSMV in field samples. Makkouk and Kumari [13] found that tissue blotting is more practical than 
regular ELISA. It could be completed in less than four hours without sacrificing sensitivity. It is cheaper and does not require sophisticated facilities. Both ELISA and DBIA require extraction of viral antigen into a suitable buffer. Direct tissue blotting DTB require minimal preparation of tissue samples for detection of plant virus and mycoplasma-like organism $[11,35]$.

\section{Detection of virus in floral parts, pods, seeds, seed parts and seedlings}

Frosheiser [43], mentioned that AMV was transmitted to alfalfa seeds at a much higher frequency through male gametes (pollen) than through females gametes (ovules). The transmission frequency through pollen in all tests ranged from 0.5 to $26.5 \%$ and transmission through the ovules ranged from 0 to $9.5 \%$. Transmission through both pollen and ovules was much less at a constant temp of $29 \pm 1 \mathrm{C}$ than at 18 $\pm 2 \mathrm{C}$ or $24 \pm 2 \mathrm{C}$. Hemmati and Mclean [44], discovered the percentage of alfalfa mosaic virus (AMV)-infected seeds was determined in the commercial production of seven different cultivars of alfalfa. Seed transmission of AMV ranged from 0.6 to $10.3 \%$. The transmission of AMV through pollen and the ovules of the infected alfalfa plants were shown. Ovule transmission ranged from 0.5 to $6.0 \%$ and pollen transmission varied from 1.0 to $14.0 \%$. Under greenhouse conditions, there was a reduction of 30.8-34.6\% in germination and a reduction of $45.1-68.6 \%$ in yield of seed by AMV-infected alfalfa. No systemic infection from the infected pollen in the normal or male-sterile female parents was detected. The susceptibility of two different cultivars of alfalfa, Sonora 70 and Mesa Sirsa 034, to AMV is compared. Bailiss and Offei [45], found that the incidence of alfalfa mosaic virus (AMV) in lucerne seed and pods during maturation, when monitored by sap transmission to Phaseolus (infective virus) and ELISA (AMV antigen), showed that infective virus incidence decreased rapidly with maturation, whereas antigen incidence declined slowly and was always higher than infective virus. Infective virus and antigen incidence were higher in mature seed of cv. Maris Kabul than cv. Europe because virus inactivation/degradation was more rapid in cv. Europe. Seed infection with virus originating from pollen, ovules or both was found in pods and seeds 12-15 days after pollination between healthy or AMVinfected plants; this was before maturation-associated virus inactivation. Ovule transmission was more frequent than pollen transmission. AMV antigen was present in embryos and testas of mature seed; infective virus only in embryos. Noninfective butELISA-positive antigen in testa extracts accounted for the higher incidence of 'seed-borne AMV' compared with embryo-associated seed transmission to seedlings. Tests with dry mature seed either underestimated (infectivity tests) or overestimated (ELISA) eventual seedling infection. Infectivity and ELISA tests gave identical incidence values for 17 to 29-day-old seedlings. Fegla, et al. [27] reported that infectivity test, indirect ELISA and tissue blot immunoassay (TBIA) were used to detect alfalfa mosaic alfamovirus (AMV) in intact seeds, seed parts and seedlings of two alfalfa cultivars. ELISA was more sensitive than infectivity test for detection AMV in seeds, seed coats embryos and seedlings. When TBIA was used for testing 21 days old seedlings, higher proportion of infected was detected as compared with indirect ELISA or infectivity test. TBIA proved to be simpler and more practical than ELISA. Fegla, et al. [46-49] mentioned that infectivity test and indirect ELISA were used for detection of alfalfa mosaic alfamovirus (AMV) in flowers, pods, intact seeds and seed parts of alfalfa c.v. ElWadi El-Gadid during maturation.

\section{References}

1. Abd El-Aziz MH. Hamza KA, Younes HA. Serological and Molecular Studies on potato virus Y. 2019; 85. NOOR Publishing. ISBN: 978-6200-06997-9.

2. Fegla GI, El-Mazaty MAA. Distribution of certain viruses affecting cucurbits in Egypt and susceptibility of cucurbit cultivars to the most prevalent one. Alex J Agric Res. 1981; 1: 247-258.

3. Abd El-Aziz MH. Detection of certain plant viruses. M.Sc. Thesis. Fac. Of Agric. (Saba-Basha) Alex Univ Egypt. 2000; 118.

4. Fegla GI, El-Samra IA, Younes HA, Abd El-Aziz MH. Plain and Filter papers as solid carriers for detection of three plant viruses by dot and tissue blot immunoassays. Adv Agric Res. 2001b; 6: 755-761.

5. Naidu RA, Hughes JDA. Methods for the detection of plant viral diseases in plant virology in sub-Saharan Africa, Proceedings of plant virology, IITA, Ibadan, Nigeria. Eds. Hughes, JDA Odu B. 2003; 233-260.

6. Abd El-Aziz MH, Younes HA. Detection of Cucumber mosaic cucumovirus in infected cowpea plants (Vigna unguiculata L.) from northern Egypt. Novel Research in Microbiology J. 2019; 3: 326-340.

7. Kohler G, Milsten C. Continuous culture of fused cells secreting antibody of predefined specificity. Nature. 1975; 256: 495-497.

8. Clark MF, Adams AN. Characteristics of the Microplate Method of Enzyme-Linked Immunosorbent Assay for the Detection of Plant Viruses. J gen Virol. 1977; 34: 475-483.

PubMed: https://www.ncbi.nlm.nih.gov/pubmed/323416

9. Lawson $\mathrm{RH}$. Controlling virus diseases in major international flower and bulb crops. Plant Dis. 1981; 65: 780-786.

10. Koenig R. ELISA in the study of homologous and heterologous reaction of plant viruses. J Gen Virol. 1978; 40: 309-318.

11. Lin NS, Hsu YH, Hsu HT. Immunological detection of plant viruses and mycoplasmalike organism by direct tissue blotting on nitrocellulose membranes. Phytopathology. 1990; 80: 824-828.

12. Makkouk KM, Kumari SG. Detection of ten viruses by the tissue-blot immunoassay (TBIA). Arab J Plant Protection. 1996; 14: 3-9.

13. Hamza KA, Abd El-Aziz MH, Behiry SI, Younes HA. Isolation and purification of potato virus $\mathrm{y}$ isolate infecting potato (Solanum tuberosum I.) in al-nubaria region. Middle East J Agri Res. 2018; 7: 1201-1207.

14. Younes HA, Aseel DG, Abd El-Aziz MH. Identification and purification of cowpea mosaic comovirus isolated from infected cowpea (vigna unguiculata I.) In northern Egypt. Int J Agri Environ Res (IJAER). 2018; 4: $206-212$.

15. Pesic Z, Hiruki C. Comparison of ELISA and dot hyperidization for detection of alfalfa mosaic virus in alfalfa pollen. Can J Plant Pathol. 1988; 10: 116-122. 
16. Castello JD, Hibben CR, Jacobi V. Isolation of tomato mosaic virus from lilac. Plant Dis. 1992; 76: 696-699.

17. Lommel SA, Mc Cain AH, Morris TJ. Evaluation of indirect enzymelinked immunosorbent assay for the detection of plant viruses. Phytopathology. 1982; 72:1018-1022.

18. Voller A, Bidwell DE, Bartlett $A$. The enzyme-immunosorbent assay. Flowline press. Guernesy, UK. 1977; 43.

19. Gillaspie AG. Hopkins MS. Spread of peanut stripe virus from peanut to soybean and yield effect on soybean. Plant Dis. 1991; 75: 11571159.

20. Hammond J, Chastagner GA. Field transmission of tulip breaking virus and serologically related potyviruses in tulip. Plant Dis. 1989; 73: $331-336$

21. Fegla GI, El-Samra IA, Younes HA, Abd El-Aziz MH. Comparative studies for detection of Tomato Mosaic Tobamovirus (ToMV), Cucumber Mosaic Cucumovirus (CMV) and Potato Y Potyviruses (PVY). Adv Agric Res. 2001; 6: 239-254.

22. Bar-Joseph M, Moscovitz M, Sharafi Y. Reuse of coated enzyme-linked immunosorbent assay plates. Phytopathology. 1979; 69: 424-426.

23. Abd El-Aziz MH, Behiry SI, Younes HA, Hamza KA. The relationship and relativity between three isolates of Potato virus $Y$ Potyvirus infecting potato (Solanum tuberosum L.) at Alexandria and El-Beheira governorates in northern Egypt. Novel Research in Microbiol J. 2019; 3 440-452.

24. Hawkes R, Niday E, Gordon J. A dot-immunobinding assay for monoclona and other antibodies. Anal Biochemical. 1982; 119: 142-147.

PubMed: https://www.ncbi.nlm.nih.gov/pubmed/7072935

25. Powell CA. Detection of three plant viruses by dot - immunobinding assay. Phytopathology. 1987; 77: 306-309.

26. Abd El-Aziz MH. Studies on some viruses infecting cowpea plants. NOOR Publishing. 978-620-0-06651-0.

27. Fegla GI, El-Samra IA, Younes HA, Abd El-Aziz MH. Optimization of dot immunobinding assay (DIA) for detection of tomato mosaic virus (ToMV). J Advances in Agric Res. 2000; 5: 1495-1506.

28. Zheng GY, Kositratant WC, Gumpf DJ. Detection of plant viruses using Dot - immunobinding assay. Chinese J Virol. 1988; 4: 150-156.

29. Berger PH, Thornbury DW, Pirone TP. Detection of pictogram quantities of potyviruses using a dot immunobinding assay. J Virological Methods. 1985; 12:31-39.

PubMed: https://www.ncbi.nlm.nih.gov/pubmed/3935655

30. Al Khalaf M, Kumari SG, Haj Kassem AA, Makkouk KM, Al Chaabi S. Use of the Two Faces of Nitrocellulose Membrane in Tissue Blot Immunoassay for the Detection of Bean yellow mosaic virus and the Possibility of its Mechanically Transmitted from the Printed Membrane to the Host Plant. Arab J Plant Protection. 2009; 27: 91-94.

31. Makkouk KM, Kumari SG. Low cost paper can be used in tissue blot immunoassay for detection of cereal and legume viruses. Phytopathologia Mediterranea. 2002; 41: 275-278.

32. Hsu HT, Lawson RH. Direct tissue blotting for detection of tomato spotted wilt virus in Impatiens. Plant Disease. 1991; 75: 292-295.

33. Lina Katul V, Naiss HJ, Makkouk KM, Lesemann DE, Casper R.
Characterization and serology of virus-like particles associated with faba bean necrotic yellows. Ann Appl Biol. 1993; 123: 629-647.

34. Sherwood JL. Comparison of a filter paper immunobinding assay, western blotting and an enzyme-linked immunosorbent assay for the detection of wheat streak mosaic virus. J Phytopathol. 1987; 118: 68-75.

35. Makkouk KM, Hsu HT, Kumari SG. Detection of three plant viruses by Dot-Blot and Tissue-Blot immunoassays using chemiluminescent and chromogenic substrates. J Phytopathol. 1993; 139: 97-102.

36. Heide $M$, Lang L. Detection of Potato leaf roll virus and potato viruses $\mathrm{M}, \mathrm{S}, \mathrm{X}$ and $\mathrm{Y}$ by dot immunobinding on plain paper. Potato Research. 1988; 31: 367-373.

37. Lange L, Jomantor A, Heide $M$. Testing seeds for viruses by dot immunobinding (DIB) directly on plain paper. Tidsskrift-for-Planteavl. 1989; 93: 93-96.

38. Banttari $\mathrm{EE}$, Goodwin $\mathrm{PH}$. Detection of potato virus $\mathrm{S}, \mathrm{X}$, and $\mathrm{Y}$ by enzyme-linked Immunosorbent assay on nitrocellulose membranes (Dot-ELISA). Plant Dis. 1985; 69: 202-205.

39. Hsu HT, Hibino H, Cabauatan PQ. Development of serological procedures for rapid, sensitive and reliable detection of rice grassy stunt virus. Plant Dis. 1990; 74: 695-698.

40. Zagula KR, Barbara DJ, Fulbright DW, Lister RM. Evaluation of three ELISA methods as alternatives to ISEM for detection of the wheat spindle streak mosaic virus. Plant Dis. 1990; 74: 974-978.

41. Klein RE, Wyatt SD, Kaiser WJ, Mink GI. Comparative immunoassays of bean common mosaic virus in individual bean (Phaseolus vulgaris) seed and bulked bean seed samples. Plant Dis. 1992; 76: 57-69.

42. Lockhart BEL, Maataoui MEL, Carroll TW, Lennon AM, Zaske SK. Identification of Barley yellow striate mosaic virus in Morocco and its field detection by enzyme linked immunosorbent assay. Plant Disease 1986; 70: 1113-1117.

43. Frosheiser FI. Alfalfa Mosaic Virus Transmission to Seed Through Alfalfa Gametes and Longevity in Alfalfa Seed. Phytopathology. 1974; 64: $102-105$

44. Hemmati K, Mclean DL. Gamete-seed transmission of alfalfa mosaic virus and its effect on seed germination and yield in alfalfa plants. Phytopathology. 1977; 67: 576-579.

45. Bailiss KW, Offei SK. Alfalfa mosaic virus in Lucerne seed during seed maturation and storage, and in seedlings. Plant Pathology. 1990; 39 539-547.

46. Fegla GI, Fath-Allah MM, Younes HA. Alfalfa mosaic alfamovirus in alfalfa floral parts, pods and seeds at different stages of development. J Agric Sci Mansoura Univ. 2004; 29: 4931-4939.

47. Fegla GI, Younes HA. Isolation of alfalfa mosaic virus from pepper in Alexandria Governorate. Adv Agric Res. 1999; 4: 827-836.

48. Fegla GI, El-Samra IA, Noaman KA, Younes HA. Host range, transmission and serology of an isolate of tomato yellow leaf curl virus from tomato of plastic houses in northern Egypt. Proceeding of the first Scientific Con of Agric Sc Fac of Agric Assiut. 1997; 1: 549-568.

49. Fegla GI, Fath-Allah MM, Ali MH. Detection, identification and purification of Cowpea mosaic virus Comovirus isolated from naturally infected fooder cowpea plants (Vigna unguiculata) in Egypt. Egyptian J Applied Sci. 2006; 21: 41-55. 